\title{
Husserl on the Unconscious and Reduction
}

\author{
Alice Togni \\ University of Salento in Lecce \\ Paris-Sorbonne University (Paris IV) \\ alicetogni89@gmail.com \\ Received 4 February 2018; accepted 30 April 2018; published 30 September 2018.
}

\begin{abstract}
Is there intentionality in the inner most level of the soul? Do we have experience of what is unconscious? And, supposing that such an experience might exist, is it possible to perform reduction on it? In this regard the present paper aims to investigate, from a phenomenological point of view, the process of "raising awareness" of what is unconscious, trying to understand if there is (or if there can be) a connection between this process and the methodological concept of "reduction" developed by Husserl. Particular attention is paid to the specific type of reduction called "psychological reduction," which, according to Husserl, provides access to the pure soul, the pure field of psychological experience.
\end{abstract}

Keywords: intentionality; phenomenology; psychoanalysis; reduction; unconscious.

\section{Introduction}

But with the most inner soul level we have a completely different type of problem, that of disclosing its intentionality, of investigating its hidden life, to raise awareness of what is unconscious, to point out, to fix and to describe - through reflexion — what was and is unreflected experience, flowing life, as something that is sunk, but not unreachable: it cannot be nothing. The intention here is to obtain systematic and methodical experience from the occasional experience of the soul. (Husserl, 1925a, p. 13)

This quotation introduces the main themes of our present inquiry: we have to deal with "the most inner soul level" and, within it, we intend to obtain "systematic and methodical experience." Phenomenologically speaking, we need to perform epoché and reduction. Considering that in Ideas I Husserl presents his own method as a "step-by-step reduction" (Husserl, 1982, p. 66) and, correlatively, speaks of different types of reduction as progressive stages of this method, we should focus on the sole way of reduction that will enable us to deal with the soul. There is actually a psychological reduction in Husserl, namely a reduction specifically directed at the psychic life, but how far may this reduction extend? 
Does the unconscious fall under it? There are two possibilities: the reduction excludes the unconscious from the field of phenomenological research-we cannot have systematic and methodical experience of it —or the unconscious remains as "residuum." Tertium non datur: no third possibility is given in Husserlian phenomenology.

Since we know that what is left by phenomenological bracketing is pure consciousness (psychological or transcendental pure consciousness, depending on which reduction is employed and, in parallel, on what phenomenological level the investigation is conducted), the first option seems to be the case. That being said, how is it possible to carry out a phenomenological analysis of the unconscious in the purity acquired through reduction? It sounds like a contradiction: do we have pure unconscious? So, what about the unconscious? To find an answer to this question, we need to clarify the notion of unconscious in Husserl. This conceptual clarification will be discussed in the first part of this paper together with a brief overview of the relationship between Husserl and Freud, followed by a methodological focus on the proper task of reduction in Husserlian phenomenology. Then, on this basis, it will be possible to understand in which sense the phenomenological process of raising awareness of what is unconscious is to be interpreted. This will enable us to answer the question previously raised about the relationship between reduction and the unconscious according to Husserl's phenomenology.

\section{The Unconscious According to Freud and Husserl}

Husserl gives a very specific meaning to the unconscious (Lohmar \& Brudzinska, 2011; Legrand \& Trigg 2017) which differs from the one-indeed more famous - outlined by Freud. Husserl (1859-1938) and Freud (1856-1939), the founder of phenomenology and the founder of psychoanalysis respectively, were contemporaries, and they both attended Brentano's lectures in Vienna (Freud between 1874 and 1876, Husserl ten years later). Unfortunately, there is little information about the knowledge they had of their respective investigations, and it is difficult to retrace their (hypothetical) reciprocal influence.

It is known that only two little works by Freud are to be found in Husserl's personal library (Holenstein, 1972, p. 321), namely his 1909 lessons On Psychoanalysis and his 1936 edition of Self-portrait, both lacking any underlined parts or notes - which are instead present in another psychoanalytic work that Husserl owned, The 1912 New York Lectures on the Theory of Psychoanalysis by Jung. Moreover, Husserl rarely mentions psychoanalysis in his writings: one of these quotations occurs in Ideas II (Husserl, 1989, p. 234) when he speaks of lived experiences in terms of sediments of earlier acts or emerging apperceptive unities in analogy with them that are not necessarily completely rational (as when sensibility and passivity are involved). According to Husserl, these kinds of lived experiences have psychic grounds, namely they are motivated in the "obscure" background of psychic life and these motives "are often deeply buried but can be brought to light by psychoanalysis" (Husserl, 1989, p. 234). One more reference to psychoanalysis is to be found in The Crisis of European Sciences and Transcendental Phenomenology (1970), where Husserl 
distinguishes between different types of intentionality, including unconscious intentionality: "this would be the place for those repressed emotions of love, of humiliation, of ressentiments, and the kinds of behaviour unconsciously motivated by them which have been disclosed by recent depth-psychology" (Husserl, 1970, p. 237).

This unconscious intentionality is indeed a field of research that phenomenology and depth-psychology have in common, but, on the other hand, Husserl always stresses that phenomenology and psychoanalysis must not be confused. In fact, no identification between them is possible. The latter makes use of modes of validity-like certainties of being and of value - which are usually applied in the natural attitude that phenomenology puts in brackets: psychoanalysis keeps having the world's validity as ground without reaching that radical attitude required from both phenomenology as rigorous science and pure psychology as genuine immanent investigation of the soul.

In fact, in pure and truly descriptive psychology the researcher is "the absolutely disinterested psychological observer" (Husserl, 1970, p. 244) that "denies himself every manner of being cointerested" in his subject matter (p. 238) and by means of methodological bracketing makes "experienceable and thematizable, in their own essential purity, the subjects which in natural world-life are experienced and experience themselves as standing in intentional-real relations" (pp. 243-244), while psychoanalysis remains in the mundane world and therefore does not fall within this definition of pure psychology. Faced with this discrepancy, the relationship between phenomenology and psychoanalysis appears problematic.

In this respect, it is worthwhile to consider what Paul Ricœur wrote in his well-known essay On Interpretation (1970) where, on the one hand, he agrees with Husserl by saying that phenomenology and psychoanalysis do not coincide, but, on the other hand, he affirms that "phenomenology does give an understanding of psychoanalysis, but only through approximation" (Ricœur, 1970, p. 390), because the approach pursued by psychoanalysis, as a unique and irreducible form of praxis, holds a record, "puts its finger on what phenomenology never perfectly attains, namely, our relation to our origins and our relation to our models, the id and the superego" (p. 418). Seen from this perspective, phenomenology couldn't get access to the "three realms, regions, provinces" into which Freud divides "the individual's mental apparatus" (Freud, 1990, p. 71), namely the id, the superego, and the ego.

Husserl, for his part, does not shrink from deeply analysing the sphere of inhibition and satisfaction of impulses. On the contrary, he even speaks of an impulsive intentionality [Triebintentionalität] (Husserl, 1973b, pp. 148, 594; Behnke, 1997, p. 665; Ales Bello, 2007, p. 9) by which he intends to extend and open subjective experience (Brudzinska, 2006, p. 56). This impulsive intentionality - characterized by gradualism, namely different degrees of intensity (Lee, 1993, p. 183) — must be understood as original affective passive synthesis in genetic phenomenology (Yamaguchi, 2001, p. 223) and indeed it is exactly the genetic aspect that is the most interesting intersection between the phenomenological approach and the psychoanalytic one (Ales Bello, 2016, p. 62). Actually, Husserl firmly believes that only in a rigorous phenomenological survey lies what is radical for 
the clarification of what is really subjective fact in these psychoanalytical matters (Husserl, 2013, p. 126), namely only phenomenology can offer a preliminary interpretation of the Freudian psychoanalysis (Husserl, 2013, p. 126), and not the reverse. That is why Husserl thinks it is phenomenology and not psychoanalysis that deserves primacy as radical investigation: he wants to show that phenomenology leads an "archaeological" inquiry into consciousness, more original and deeper than that conducted by Freud with his psychoanalytic method. The phenomenological process of going back to the genesis of constitution brings out the intentional structure of consciousness and identifies several levels of intentionality within it: there is not just active intentionality, there is also latent, passive intentionality, and it is precisely in this direction that the unconscious is to be understood.

As Eugen Fink stressed in his Appendix XXI to Husserl's Crisis (1970) concerning exactly the problem of the unconscious, we are talking about the long methodical way from intentional elementary analyses to an intentional theory of the unconscious. This does not mean, as it may seem, that we absorb the unconscious in consciousness, distorting its essence and foreclosing the possibility of getting access to it. On the contrary, Husserl wants to fill a gap in the way many disciplines - including psychoanalysis - proceed, namely the nä̈vité related to the omission of a preliminary and fundamental investigation of consciousness. In other words, how it is possible for psychoanalysis to speak about the unconscious without first exploring what consciousness is? While Freud thinks - as he says in his New Introductory Lectures on Psycho-Analysis in 1933-that "there is no need to discuss what is to be called conscious" (Freud, 1990, p. 69), according to Husserl the preliminary investigation of consciousness is instead fundamental: "what is conscious" cannot be taken for granted. And in full agreement with him Fink underlines that "only after an explicit analysis of consciousness can the problem of the unconscious be posed at all" (Husserl, 1970, p. 387).

But what really was Freud's account of the unconscious? It is not possible to provide all the details of Freud's concept of the unconscious here, but nevertheless we need to briefly outline the main distinctive features that characterize it, since such understanding provides a reference point in order to correctly interpret Husserl's theoretical approach. First, it must be said that Freud, who bases his understanding of the unconscious on clinical-empirical observation (Bernet, 2003, p. 199), highlights several nuances in the concept of the unconscious: in a purely descriptive sense, the unconscious is that psychical process "whose existence we are obliged to assume - for some such reason as that we infer it from its effects - but of which we know nothing" (Freud, 1990, p. 69). Second, Freud introduces, in further considerations, the distinction between the unconscious that can be easily transformed into something conscious - this is what he calls "preconscious," which is latent and can become conscious again - and the unconscious for which this transformation is difficult or even impossible. And thirdly, it is necessary to distinguish the unconscious in a topographical sense from the unconscious in a systematic sense: only in this way is a genuine insight into the unconscious possible, only this approach enables us to grasp the unconscious as "an extensive and important field of mental life which is normally withdrawn from the ego's knowledge" (Freud, 1990, p. 70) and therefore as a system in conflict 
with the ego. This specific notion of "unconscious" is interchangeable with what Freud calls "id"- a term borrowed from Nietzsche and Georg Groddeck - and denotes "a mental province rather than a quality of what is mental" (Freud, 1990, p. 70), a province which is totally "alien to the ego" (p. 71). The question arises whether something of this nuanced concept of the unconscious is also to be found in phenomenology.

It is known that Husserl too speaks about the latency and possibility of "reactivation" (Casey, 1985, p. 42) of what is unconscious, but his perspective is based on very different premises. Here, again, there is no one definition of the unconscious, but rather a multilayered investigation into the structure of consciousness. Consequently, Husserl labels "unconscious" the hidden and stratified underground of consciousness: this is a deep realm of sunken thoughts, volitions, and values within the life of the soul. Precisely because of its stratification, Husserl often speaks of "sedimentation" and identifies this multi-layered underground of consciousness with what is below the zero, but it isn't zero itself (Husserl, 2013 , p. 40). The unconscious would therefore be the "degree zero" of the vivacity of consciousness (Husserl, 2001, p. 216), "a limit-mode of consciousness" (Husserl, 1969, p. 319), that means a limit level of inactivity, a quiet repository of lived-experiences of different kinds, sedimented in fixed quietness.

Since this zero is no more than the minimum level of consciousness, the unconscious is characterised as unreflected experience, flowing life, something that is sunk but not unreachable: it cannot be nothing. The main problem is how to deal with it: in the Crisis, Husserl includes the "so much discussed" (Husserl, 1970, p. 188) problem of the unconscious in the much broader transcendental problem of constitution and dissociates himself from the way in which psychology (both the psychoanalytic-oriented and the descriptive one) seeks "to penetrate into the obscure realm of the unconscious" (p. 246), namely by proceeding "quite in the manner of natural science" (p. 246) or even by relying on "mythical theories set up on the basis of an obscure empirical procedure about the true essence of life" (p. 386). As claimed by Husserl, this field of huge problems (Husserl, 1973b, p. 34) requires a new approach instead: the unconscious must be understood in terms of passive, latent intentionality and it must be treated accordingly.

It should first be noted that the unconscious also includes what Husserl calls "retentional" (Husserl, 2001, p. 216): for what is sunk in the unconscious, passive and pre-active intentionality, there is always the possibility to emerge, surfacing from the depth-like "an island" (p. 476) - and coming to the light of consciousness. In fact, what ceases to be conscious keeps streaming forth in its constitutional style: the entire intertwined, merged intentionality is stored in the sedimented unconscious; this unconscious is not "a mysterious nothing," but "rather, there is internally a submerged life only in the form of phenomena that are not prominent" (pp. 526-527). Consequently, Husserl ranks the unconscious among the modes of inactivity (Husserl, 2008a, p. 461), but at the same time he always underlines the possibility for what is sunk in this sedimentation to be awakened again, to become "intuitively visible in the way and in the framework of explicit clarity and of prominence" (Husserl, 1973b, p. 347). 
In the case of faded perception, for instance, a retentional acquisition can live again as intuitively visible recollection and enter into synthesis with a new perception (Husserl, 2008a, p. 364). And this is exactly where Husserl's analyses of passive syntheses come in, namely the kind of syntheses that phenomenology is able to grasp by regressing "to the most elementary level of pre-predicative, pre-reflective intentional consciousness" (Biceaga, 2010, p. xvi). Moreover, in addition to this possibility, for the realm of unconscious life to be awakened again and again, other aspects should be considered as well. Given that both the sinking into layered sedimentation and the possibility of awakening are potentially infinite processes (Husserl, 2001, p. 244), there is also "the phenomenon of the overlapping of several pasts that are awakened together, and moreover, the phenomenon of reproduction and the phenomena of association and of associative fusion" (p. 527). According to Husserl, all these considerations allow us to speak of a "phenomenology of the so-called unconscious," the aim of which is "to shed some phenomenological light in this darkness" (p. 201), namely to provide the proper method for approaching the unconscious.

\section{Reflection and Reduction}

Husserl intends to phenomenologically account for the process of raising awareness of what is unconscious [das Bewusstmachen des Unbewussten] (Husserl, 1925a, p. 13; Freud, 1944, pp. 451-452), trying to lose the "enigmas" (Husserl, 2001, p. 165) related to it and to its varying modes of becoming conscious. In that sense, what he says in paragraph 22 of Ideas II when presenting the pure Ego as Ego-Pole inseparable from its lived-experiences is very enlightening: he observes, in fact, that if lived-experiences-for example in the specific form of cogito - sink down into inactuality, in a certain sense the pure Ego also sinks down into inactuality (Husserl, 1952, p. 106). Figuratively speaking, Husserl says that the pure subject in connection with its flux of Erlebnisse can make an entrance or an exit, step forth or step back (p. 109), but actually this does not mean that the pure Ego can disappear, because this is not possible: it is always present in its acts, just in different ways-namely what changes is the how, the manner in which the Ego has lived-experiences. One of these manners is exactly the one pertaining to the unconscious. And as a result of this, Husserl states that in principle the pure Ego can enter into any unaccomplished (in a determinate sense: unconscious, un-alert) intentional lived experience, it can bring the light of alert consciousness to those lived experiences that have receded into the background and are no longer being performed (Husserl, 1952, p. 115). Thus, the pure Ego can also grasp the unconscious, which itself — as has already been said — is not "a nothing," but rather a stage of latency of previously active intentionality that can be re-activated.

This kind of consideration is to be found especially in the mid-term and final phase of Husserl's thought, but, in a certain way, the theme of the unconscious was already present before, for example in the Second Logical Investigation (Husserl, 1975, p. 125) and in the 1906/1907 Introductory Lectures on Logic and Theory of Knowledge (2008) where, with regard to consciousness in the form of attention, Husserl underlined that unconsciousness was not to be intended as "mere privation" (Husserl, 2008b, p. 249), but as a quality of 
consciousness. In this sense the unconscious is also what is unheeded: although it is unnoticed, in fact, this is still a mode of consciousness and precisely that of inattention. Indeed, this is another way of understanding the unconscious: speaking about a "retentional element that has become unconscious, the just-past that has become unconscious" (Husserl, 2001, p. 525) is not the same as saying that the unconscious is what "is already unclear from the beginning [...] something that is not grasped and that toward which the ego does not let itself to be drawn even one step of the way" (Husserl, 2001, p. 525). Moreover, it is possible to consider the unconscious in a third sense, namely as unconscious background: this expression may refer both to the unnoticed objective background of consciousness - whereby objects are still given to us even if we don't pay attention to them (Husserl, 2008b, p. 252) - and to the inner zero-horizon (Husserl, 2006, p. 184) as "the substratum of sedimented prominences, which, as a horizon, accompanies every living present and shows its continuous changing sense in the "awaking," it refers back the entire intentional genesis" (Husserl, 1969, p. 319).

At this point, it is worth focusing on the unconscious intended as sedimented intentionality to which the possibility of awakening belongs: "what does the re-emergence from the background mean?" (Husserl, 2001, p. 525) and how can this happen? Husserl notes, firstly, that reflection plays a role of primary importance in this context: it is precisely through reflection that we can grasp not only individual background lived experiences but also whole stretches of the stream of consciousness which would lack all Ego-activity. Despite all the obscurity and all the confusion which adheres to the proper character of such stretches, we can grasp insightfully the most general essential properties (Husserl, 1973b, p. 106), namely we can grasp their intentional character (despite at this stage lying in latency). Moreover, Husserl emphasises that the Ego as "pole" carries within it both activity and passivity, it is a unity of awake and hidden life (p. 34), a merged unity (p. 53) wherein the hidden dimension is precisely the unconscious as "a peculiar modality for the discreteness of the monad" (Husserl, 2001, p. 635). In this matter, reflection is indeed helpful by making thematic the ego as functioning pole with its intentional life, but it is unable to catch all the layers of lived-experiences belonging to consciousness, regardless of whether they are active, passive, or simply sunk in latency. Here are the limits of reflection. The awake ego that reflects upon itself can catch a glimpse into one section of its past state of unconscious (Husserl, 1973b, p. 53), but such a backward turning reflection (p. 53) is not sufficient to really grasp the unconscious in its peculiar intentional modification of the patent being of consciousness.

However, from a phenomenological point of view reflection is not merely psychological self-experience, which is only interested in grasping what is properly "psychic" without questioning either how the world is given to us or the "enigma" (Husserl, 1930, p. 21) of how what is subjective, psychic can get into it. On the contrary, Husserl distinguishes different levels of reflection (Husserl, 1922) and stresses that the phenomenological epoché gives new dignity to the natural reflection (Husserl, 1968, p. 532), since the natural mode of performance of streaming life by the epoché takes a turn of performance, in which the psychological world-life of my ego as human takes a turn: through the epoché in my 
natural experiencing I see intuitively the transcendental (Husserl, 2002b, p. 452). All this leads to the transcendental reflection, namely that level of reflection which has the transcendental life as thematic field. But how should one approach the unconscious? According to Husserl, to the sphere of the unconscious belong Erlebnisse upon which we cannot carry out any kind of reflection. It is the case, for example, of the background lived-experiences: we can reflect upon perception, we can describe it, but we cannot reflect upon its background lived-experiences, we can only assume it on the basis of vague memories of past perceptions (Husserl, 1973b, p. 83). As a consequence, a genuine analysis of this background is impracticable, since it remains inevitably imperfect and incomplete.

So how is it possible in phenomenology to point out, to fix, and to describe what is unconscious? Having established that reflection is not enough to fulfil this purpose, we need a systematic approach: what is required is exactly that methodological way of proceeding that Husserl calls "reduction." But what kind of reduction should be performed in relation to the so-called "unconscious"? Given that both (depth) psychology and phenomenology aim at grasping the unconscious, one may think that what is needed here is a kind of "psychological reduction," namely a reduction which has the soul (Seele), the psychic dimension as its proper theme. Husserl observes in fact that the soul has the curious characteristic of letting itself be reduced (Husserl, 1925a, p. 1): it is therefore quite legitimate to assume that such a psychological reduction is not only possible, but even required. This raises the question of whether the unconscious falls within this reduction of the soul. In a certain sense, the answer seems to be positive, since Husserl, in one manuscript dated "Chiavari September 1930" and explicitly entitled "What is this: psychological reduction?", by linking this psychological reduction to the attitude of pure psychology, claims that it provides access to what is purely subjective, regardless of its being active or passive (Husserl, $1925 \mathrm{~b}, \mathrm{p} .1$ ). The problem is that this apprehension only ever occurs within the framework of the objective apperception "human being," namely it is anchored to the natural attitude and cannot entirely shake off its naivety. For this reason, the unconscious continues to be something obscure and inexplicable: its essence, namely its sense, remains unattainable and the possibility of a proper understanding of it is precluded. The psychological reduction Husserl talks about can only, at best, provide us with vague insight into the unconscious, whose understanding requires instead another way of proceeding, namely the transcendental-phenomenological reduction.

The psychological reduction may nevertheless be a doorway. In fact, according to Husserl the psychological and the transcendental investigations are carried out on different levels, but they move forward in the same direction overlapping — in parallel — with each other and a change of attitude, based on these premises, is always possible, namely it is possible to switch (reversibly) from the psychological to the transcendental. Consequently, the psychological reduction acts as a preliminary step to the transcendental-phenomenological one, paving the way for a proper phenomenological understanding of the unconscious. Through the shift from the one attitude to the other, a splitting of the ego takes place, so that the ego becomes a "disinterested spectator" of its own life and, in such an attitude, notes all the infinite manifold occurrences that belong, only unfixed (unconscious), to the 
lived stream of consciousness of the natural ego (Husserl, 2002a, p. 367). What is to be found as "residue" after reduction, in the pure immanent contemplation of the phenomenological attitude, is thus the pure transcendental ego and, within it, also what we have phenomenologically characterized as the "unconscious." We find the unity of the stream of lived-experiences as immanent intentional unity that constitutes itself ad infinitum, as indelible. We find the ego, me as both active and undergoing/passive. Moreover, we find genesis, the way in which consciousness arises from consciousness in passive motivation; we find the necessary laws of reproduction, association, and the sedimentations of past experiencing in present experiencing (Husserl, 1973b, pp. 52-53). This means that both active and passive sides are enclosed in the pure ego resulting from phenomenological reduction: within this reduction, the unconscious is therefore included as a mode of the transcendental consciousness.

\section{Conclusion}

The opening question of this paper was two-sided: whether the unconscious may fall under any kind of reduction and in which sense the phenomenological process of raising awareness of what is unconscious [das Bewusstmachen des Unbewussten] is to be understood. In accordance with Husserl's phenomenology, we have found an answer by providing a definition of the unconscious in terms of passive intentionality, which belongs to consciousness in the mode of inactivity but still has the possibility of being awakened again in the context of passive syntheses. In this sense the unconscious has been characterised as something that is sunk but not unreachable, and the transcendental-phenomenological reduction appeared as the only viable way to reach this deep dimension, to bring light into this "night," to reactivate this inert level of consciousness by disclosing its intentionality. Such an achievement cannot be realized under a simply psychological reduction that remains "victim of the pure inner attitude" (Husserl, 2001, p. 216): we realized "that the path is cleared from here toward a universal theory of the genesis of a pure subjectivity, and, in particular, initially in relation to its lower level of pure passivity" (p. 216). This kind of research can be pursued only by a genuine constitutive, transcendental phenomenology.

In view of these considerations, the great distance between Husserl's and Freud's approaches to the unconscious becomes clearer. Representatives of two distinct and unusual methods, they started from very different premises, but they had the same direction of research in common - inwards. Perhaps it is no coincidence that they both took up Augustine's lesson Noli foras ire, in te ipsum redi, in interiore homine habitat veritas. Husserl ended his 1929 Paris Lectures with this Augustinian quotation. Approximately ten years before Freud had used almost the same words in his 1917 essay "A Difficulty in the Path of Psycho-Analysis" (1955): "Turn your eyes inward, look into your own depths, learn first to know yourself!" (1955, p. 143). According to Husserl, the transcendental phenomenological method is the instrument by which this self-knowledge is to be achieved, and, to this extent, it is the only one that can provide a solid basis for pursuing psychoanalysis as a practice with therapeutic value. 


\section{References}

Ales Bello, A. (2007). Phenomenological Hyletics: The Animal, the Human, the Divine. In Analecta Husserliana. The Yearbook of Phenomenological Research (Vol. XCIV). Dordrecht, the Netherlands: Springer.

Ales Bello, A. (2016). Il senso dell'umano: Tra fenomenologia, psicologia e psicopatologia. Roma, Italy: Castelvecchi.

Behnke, A. E. (1997). Somatics. In L. Embree (Ed.), Encyclopedia of Phenomenology. Dordrecht, the Netherlands: Springer.

Bernet, R. (2003). Unconscious consciousness in Husserl and Freud. In D. Welton (Ed.), The New Husserl: A Critical Reader. Bloomington: Indiana University Press.

Biceaga, V. (2010). The Concept of Passivity in Husserl's Phenomenology. Dordrecht, the Netherlands: Springer.

Brudzinska, J. (2006). Die phänomenologische Erfahrung und die Frage nach dem Unbewussten: Überlegungen im Anschluss an Husserl und Freud. In D. Lohmar \& D. Fonfara (Eds.), Founding Psychoanalysis Phenomenologically. Phenomenological Theory of Subjectivity and the Psychoanalytic Experience. Phaenomenologica 177. Dordrecht, the Netherlands: Springer.

Casey, S. E. (1985). Memory and Phenomenological Method. In S. W. Hamrick (Ed.), Phenomenology in Practice and Theory: Essays for Herbert Spiegelberg. Phaenomenologica 92. Dordrecht, the Netherlands: Springer.

Freud, S. (1944). Gesammelte Werke, Vol. XI, Vorlesungen zur Einführung in die Psychoanalyse. Frankfurt am Main, Germany: S. Fischer Verlag. (Original work published 1917)

Freud, S. (1955). An Infantile Neurosis and Other Works. In J. Strachey (Ed. \& Trans.), The standard edition of the complete psychological works of Sigmund Freud (Vol. XVII). (Original work published 1917-1919)

Freud, S. (1990). New Introductory Lectures on Psycho-Analysis. In J. Strachey (Ed. \& Trans.), The standard edition of the complete psychological works of Sigmund Freud (Vol. XXII). (Original work published 1933)

Husserl, E. (1922). B I 5/XI Reflexion - verschiedene Stufen bis zur transzendentalen. Unpublished manuscript. Husserl-Archives Cologne.

Husserl, E. (1925a). B I 9/I Ästhetische Wesenslehre der Natur; das Physische und Organische. Ästhetische oder deskriptive Wesenslehre des Menschen, Anthropologie, Psychologie. Das zur apriorischen Auslegung der Erfahrungswelt - rein als Erfahrungswelt. Wie ist Anthropologie und Psychologie als objektive Wissenschaft möglich. Ausführlich: das Problem des Parallelismus von Seelischem und Körperlichem (organisch Leiblichem). Unpublished manuscript. Husserl-Archives Cologne.

Husserl, E. (1925b). B I 9/III Beiblätter zu den Vorlesungen über Psychologie. Unpublished manuscript. Husserl-Archives Cologne.

Husserl, E. (1930). B I 5/VII Sinn und Funktion der Epoché. Unpublished manuscript. HusserlArchives Cologne. 
Husserl, E. (1952). Ideen zur einer reinen Phänomenologie und phänomenologischen Philosophie: Zweites Buch: Phänomenologische Untersuchungen zur Konstitution. In M. Biemel (Ed.), Gesammelte Werke: Husserliana (Vol. IV). The Hague, the Netherlands: Martinus Nijhoff.

Husserl, E. (1968). Phänomenologische Psychologie. Vorlesungen Sommersemester 1925. In W. Biemel (Ed.), Gesammelte Werke: Husserliana (Vol. IX). The Hague, the Netherlands: Martinus Nijhoff.

Husserl, E. (1969). Formal and transcendental logic. (D. Cairns, Trans.). Dordrecht, te Netherlands: Springer. (Original work published 1929)

Husserl, E. (1970). The crisis of European sciences and transcendental phenomenology. (D. Carr, Trans.). Evanston, IL: Northwestern University Press. (Original work published 1936)

Husserl, E. (1973a). Zur Phänomenologie der Intersubjektivität. Texte aus dem Nachlass. Erster Teil. In I. Kern (Ed.), Gesammelte Werke: Husserliana (Vol. XIII). The Hague, the Netherlands: Martinus Nijhoff.

Husserl, E. (1973b). Zur Phänomenologie der Intersubjektivität. Texte aus dem Nachlass. Dritter Teil. In I. Kern (Ed.), Gesammelte Werke: Husserliana (Vol. XV). The Hague, the Netherlands: Martinus Nijhoff.

Husserl, E. (1975). Hua XVIII, Logische Untersuchungen. Zweiter Band. Erster Teil. Untersuchungen zur Phänomenologie und Theorie der Erkenntnis. In U. Panzer (Ed.), Gesammelte Werke: Husserliana (Vol. XIX/1). The Hague, the Netherlands: Nijhoff.

Husserl, E. (1982). Ideas pertaining to a pure phenomenology and to a phenomenological philosophy: First book: General introduction to a pure phenomenology. In F. Kersten (Trans.), Edmund Husserl: Collected works (Vol. II). Boston, MA: Martinus Nijhoff. (Original work published 1913).

Husserl, E. (1989). Ideas pertaining to a pure phenomenology and to a phenomenological philosophy: Second book: Studies in the Phenomenology of Constitution. In R. Rojcewicz \& A. Schuwer (Trans.), Edmund Husserl: Collected works (Vol. III). Boston, MA: Martinus Nijhoff.

Husserl, E. (2001). Analyses concerning passive and active synthesis: Lectures on transcendental logic. In A. J. Steinbock (Trans.), Edmund Husserl: Collected works, (Vol. IX). Dordrecht, the Netherlands: Springer.

Husserl, E. (2002a). Einleitung in die Philosophie. Vorlesungen 1922/23. In B. Goossens (Ed.), Gesammelte Werke: Husserliana (Vol. XXXV). Dordrecht, the Netherlands: Kluwer Academic Publishers.

Husserl, E. (2002b). Zur phänomenologischen Reduktion. Texte aus dem Nachlass (1926-1935). In S. Luft (Ed.), Gesammelte Werke: Husserliana (Vol. XXXIV). Dordrecht, the Netherlands: Kluwer Academic Publishers.

Husserl, E. (2006). Späte Texte über Zeitkonstitution (1929-1934). In D. Lohmar (Ed.), Gesammelte Werke: Materialien (Vol. VIII). Dordrecht, the Netherlands: Springer.

Husserl, E. (2008a). Die Lebenswelt: Auslegungen der vorgegebenen Welt und ihrer Konstitution. Texte aus dem Nachlass (1916-1937). In R. Sowa (Ed.), Gesammelte Werke: Husserliana (Vol. XXXIX). Dordrecht, the Netherlands: Springer. 
Husserl, E. (2008b). Introduction to logic and theory of knowledge: Lectures 1906/07. In C. O. Hill (Trans.), Edmund Husserl: Collected works (Vol. XIII). Dordrecht, the Netherlands: Springer.

Husserl, E. (2013). Grenzprobleme der Phänomenologie: Texte aus dem Nachlass (1908-1937). In R. Sowa \& T. Vongehr (Eds.), Gesammelte Werke: Husserliana (Vol. XLII). Dordrecht, the Netherlands: Springer.

Holenstein, E. (1972). Phänomenologie der Assoziation. Phaenomenologica 44. Dordrecht, the Netherlands: Springer.

Lee, Nam-In (1993). Edmund Husserls Phänomenologie der Instinkte. Phaenomenologica 128. Dordrecht, the Netherlands: Springer.

Legrand D., \& Trigg D. (Eds.). (2017). Unconsciousness Between Phenomenology and Psychoanalysis. Contributions to Phenomenology 88. Dordrecht, the Netherlands: Springer.

Lohmar D., \& Brudzinska J. (Eds.). (2011). Interdisziplinäre perspektiven der phänomenologie. Neue Felder der Kooperation: Cognitive Science, Neurowissenschaften, Psychologie, Soziologie, Politikwissenschaft und Religionswissenschaft. Phaenomenologica 199. Dordrecht, the Netherlands: Springer.

Ricœur, P. (1970). Freud and Philosophy: An Essay on Interpretation. (D. Savage, Trans.). New Haven, CT: Yale University Press.

Yamaguchi, I. (2001). Triebintentionalität als uraffektive passive Synthesis in der genetischen Phänomenologie. In Alter Nr. 9 La pulsion. Paris: Éditions Alter. 